\title{
ПСИХОЛОГІЧНЕ ДОСЛІДЖЕННЯ НАВЧАЛЬНО-ПРОФЕСІЙНОЇ МОТИВАЦЇ̈ МАЙБУТНІХ ПЕДАГОГІВ
}

\author{
Римма Кириченко \\ кандидат психологічних наук, доцент, \\ доцент кафедри професійної освіти в сфері технологій та дизайну \\ Київський національний університет технологій та дизайну \\ 01011, Україна, м. Київ, вул. Немировича-Данченка, 2 \\ kirichenkorv11@gmail.com, https://orcid.org/0000-0002-2020-9157
}

\author{
Алла Колодяжна \\ кандидат психологічних наук, доцент, \\ доцент кафедри професійної освіти в сфері технологій та дизайну \\ Київський національний університет технологій та дизайну \\ 01011, Україна, м. Київ, вул. Немировича-Данченка, 2 \\ kol-alla@ukr.net, https://orcid.org/0000-0002-5760-883X
}

\section{Анотація}

В статті розглянуто основні аспекти мотивації як психолого-педагогічного феномена. Проаналізовані умови, що впливають на формування позитивних мотивів навчальної діяльності та методи підвищення мотивації студентів до навчання. Проведено анкетування та описано результати дослідження навчально-професійної мотивації майбутніх педагогів. Метою статті є здійснення аналізу проблеми формування і проявів актуальної навчальнопрофесійної мотивації у майбутніх педагогів для підвищення рівня підготовки сучасних фахівців за спеціальністю 015 Професійна освіта (Технологія виробів легкої промисловості) в контексті успішної конкурентоспроможної професійної діяльності. Використано комплекс теоретичних та емпіричних методів, який включав аналіз, синтез, систематизацію, порівняння і узагальнення даних 3 проблеми навчально-професійної мотивації студентів, методики: «Вивчення мотивів навчальної діяльності студентів» (А. Реана, В. Якуніна), «Мотивація навчання у виші» (Т. Ільїної), анкетування, опитування, методи математичної статистики. За результатами дослідження визначено, що переважна більшість учасників задоволені методами навчання та викладання психолого-педагогічними дисциплінами i дисциплінами технічного циклу. Дані аналізу свідчать про те, що сучасна молодь розуміє важливість вищої освіти сьогодні. В більшості студентів провідними мотивами до навчання $\epsilon$ пізнавальні та професійні. Аналіз опитування показав, що, у першу чергу, до найбільш значимих мотивів навчальної діяльності ввійшли такі мотиви: стати висококваліфікованим спеціалістом (80\% студентів); набути глибокі та стійкі знання (70\% студентів); отримати інтелектуальне задоволення $(70 \%$ студентів); забезпечити успішність майбутньої професійної діяльності (63,3\% студентів). Обрання таких мотивів вказує на присутність у структурі внутрішньої мотивації наявність пізнавального інтересу, що є дуже важливим при виконанні навчальної діяльності. Позитивно впливають на внутрішню мотивацію високий професійний рівень викладачів та їхнє партнерське ставлення до студентів. Після закінчення навчання, більшість майбутніх педагогів мають намір шукати роботу за фахом, при цьому, 
рівень заробітної плати та прагнення мати власну справу є найважливішими критеріями. Як позитивну тенденцію можна охарактеризувати той факт, що 50\% опитаних спокійно, але без особливих ілюзій дивляться в майбутнє і 40\% - 3 надією та оптимізмом. Для підвищення рівня підготовки сучасних фахівців до успішної конкурентоспроможної професійної діяльності на світовому ринку праці суттєвим завданням є розвиток професійної мотивації студентів у закладах вищої освіти, доцільним є створення системи психологічного супроводу професіоналізації майбутніх фахівців 3 метою виявлення основних проблем, пов'язаних 3 початковим етапом професійної кар'єри майбутніх фахівців і для сприяння їх позитивному вирішенню.

Ключові слова: мотивація, студенти, навчальна мотивації, професійна мотивація, навчальнопрофесійна діяльність, формування позитивної мотивації.

\section{Вступ}

Динамічність суспільних процесів, зміна світоглядних орієнтирів, інтенсивний інформаційно-технологічний поступ країни, інтеграція України в європейське освітнє співтовариство з кожним днем висувають нові вимоги до підготовки педагога, формують нові стратегічні напрями розвитку вітчизняної педагогічної освіти. 3 огляду на потреби сучасного українського суспільства, сьогодні нагальною потребою є створення такої системи педагогічної освіти, яка на основі національних надбань світового значення та усталених європейських традицій забезпечує формування педагогічних працівників, здатних здійснювати професійну діяльність на демократичних і гуманістичних засадах, реалізовувати освітню політику як пріоритетну функцію держави, що спрямовується на розвиток та самореалізацію особистості, задоволення їі освітніх і духовно-культурних потреб та бути на ринку праці конкурентоздатним (Товканець, 2018). Розвитку умінь у майбутніх фахівців: креативно і нестандартно мислити, аналізувати й проводити рефлексію своїх дій, зіставляти їх з метою діяльності, знаходити оптимальні рішення, застосовувати глибокі, стійкі знання у професійній діяльності сприяє високий рівень мотивації навчальної діяльності (Скорик, 2020).

В загально-психологічному контексті мотивація є системою психологічно різнобічних стимулів, які зумовлюють поведінку і діяльність людини. Під професійною мотивацією, стосовно навчальної діяльності студентів в системі вишівської освіти, розуміється сукупність факторів і процесів, які спонукають і спрямовують їх до вивчення майбутньої професійної діяльності. Провідним фактором формування професійної компетентності студента $€$ університетське навчання, яке забезпечує його розумовий розвиток, виступає засобом організації навчання, але не стає автоматично цікавим, значимим для молодої людини, а іноді може навіть виникати негативне ставлення до пізнання, розчарування студента як суб'єкта навчально-виховної взаємодії з викладачем у значимості, практичній цінності набуття нових знань та вмінь (Занюк, 2001). Сучасні теорії академічної мотивації прагнуть пояснити поведінку студентів в академічному середовищі. Хоча здається, що кожна теорія має свої власні конструкції й унікальні пояснення, насправді ці теорії тісно пов'язані між собою. В цих теоріях вважається, що емоції і переконання викликають різні моделі поведінки, такі як прагнення до майстерності, уникнення невдач, засвоєна безпорадність і пасивна агресія (Seifert, 2004).

3 часу появи інтересу дослідників до проблеми мотивації досягнення відбулися значні зміни в структурі знань про цей феномен. Сучасні уявлення про мотивацію досягнення 
відрізняються від початкових. Разом із появою нових даних з'являються і нові питання, які потребують відповідей. Теорія самовизначення стверджує, що автономна мотивація, яка пов'язана 3 більш високою успішністю, може бути досягнута при задоволенні трьох психологічних потреб: автономії, компетентності та взаємозв'язку. Низький відсоток випускників і високий відсів студентів - дві основні проблеми, 3 якими стикаються університети вищої освіти в усьому світі. В Нідерландах це серйозна проблема. Мотивація студентів часто асоціюється 3 кращими академічними досягненнями i показниками випускних іспитів. Наприклад, мотивація студентів корелює з академічними досягненнями, такими як середній бал, і студенти 3 меншою внутрішньою мотивацією 3 більшою ймовірністю кинуть навчання (Veinia, Sluga-Miklos, 2019).

Мотивація є одним із ведучих факторів успішного навчання молодої людини, а отже, iï професійного становлення. Формування позитивної навчальної мотивації у студентів $\epsilon$ однією з умов ефективної професійної підготовки і розвитку особистості (Гуртовенко, 2017).

Підвищити якість підготовки фахівців, сформувати в них позитивну мотивацію до майбутньої професії $\epsilon$ одним із основних завдань вищої школи для забезпечення конкурентоспроможності країни на світовому рівні. Розвиток позитивної мотивації до майбутньої професії можливий лише за наявності стійкої мотивації до навчальної та пізнавальної діяльності, які пов'язані з цією професією. В закладах вищої освіти проблемі формування мотивації навчальної та пізнавальної діяльності присвячена значна кількість психолого-педагогічних праць і все ж це одне із актуальних питань психології та педагогіки.

Метою статті $\epsilon$ здійснення аналізу проблеми формування та виявів актуальної навчально-професійної мотивації у майбутніх педагогів для підвищення рівня підготовки сучасних фахівців за спеціальністю 015 Професійна освіта (Технологія виробів легкої промисловості) в контексті успішної конкурентоспроможної професійної діяльності. Завдання дослідження: 1) здійснити теоретичний аналіз основних аспектів мотивації як психолого-педагогічного феномена; 2) проаналізувати умови, що впливають на формування позитивних мотивів навчальної діяльності та методи підвищення мотивації студентів до навчання; 3) дослідити навчально-професійну мотивацію майбутніх педагогів.

\section{Методи дослідження}

Використано комплекс теоретичних та емпіричних методів, який включав: аналіз психолого-педагогічної літератури, синтез, систематизацію, порівняння і узагальнення даних 3 проблеми навчально-професійної мотивації студентів, методики: «Вивчення мотивів навчальної діяльності студентів» (А. Реана, В. Якуніна), «Мотивація навчання у виші» (Т. Ільїної), анкетування, опитування, методи математичної статистики. Крім тверджень, що давали змогу визначити рівень сформованості основних зовнішніх та внутрішніх мотивів навчальної діяльності, запропоновано питання, які стосувалися мотивів вступу, співвідношення частки навчальних дисциплін, бачення власного місця у майбутньому фаху, подальшої спеціалізації. Дослідження базувалося на загальнонаукових методологічних підходах - системному і компетентнісному.

\section{Результати та дискусії}

Аналіз останніх психолого-педагогічних досліджень різних аспектів мотиваційної діяльності студентів виявив значну увагу науковців до формування навчальної мотивації студентів різних закладів вищої освіти і спеціальностей (О. Тарнопольський), мотивів вступу 
до закладу вищої освіти (С. Бобровицька), динаміки змін мотивів на різних курсах (Н. Бордовська), умов виникнення у студентів позитивної мотивації до навчальнопізнавальної діяльності (С. Занюк).

Теоретичні та експериментальні дослідження проблеми мотивів і мотивації проводилися вітчизняними і зарубіжними вченими в таких аспектах, як: мотивація як стрижнева характеристика особистості (Л. Божович, Г. Костюк); мотив як регулятор різних видів діяльності, зокрема учіння (А. Дусавицький, Ш. Амонашвілі). В психологічних і педагогічних дослідженнях обгрунтовано різні шляхи мотиваційного забезпечення навчального процесу, зокрема: розвиток пізнавальних потреб (П. Гальперін); поєднання індивідуальних і колективних форм діяльності (І. Чередов, Ю. Мальований); використання методів проблемного навчання (А. Алексюк, I. Лернер). Питання мотивації навчальної діяльності $є$ предметом педагогічних і психологічних наукових досліджень, які проводяться в двох основних напрямках. А. Маркова виділяє два типи стратегій дослідження мотивації: 1) вивчення впливу мотивації на діяльність, зміна діяльності в залежності від актуалізації у студента різних мотивів; 2) вивчення впливу діяльності на становлення мотиваційної сфери.

Загальновідомим є факт, що формування у студентів стійкої мотивації до навчання впродовж життя, допоможе їм визначитися професійно та стати кваліфікованими фахівцями. Важливою складовою підготовки у вищій школі $є$ формування професійної свідомості майбутніх фахівців - категорії, що відображає сутність процесу професійного становлення й розвитку фахівця. Акцентується увага на формуванні фахівця вищого гатунку, культивуванні у нього пізнавальних цінностей, усвідомлення ним потреби в розвитку і самовдосконаленні, формуванні здатності до самоаналізу, самоуправління власного розвитку, що позитивно впливає на підвищення рівня готовності майбутніх педагогів до професійної діяльності. Відтак результатом професійної підготовки фахівця має стати формування його конкурентоспроможності, як показника сукупності знань, умінь, навичок, компетенцій, що забезпечують спрямованість на успішну професійну діяльність (Матвеєва, 2017).

Мотивація має різне трактування: це і фактори, які підтримують і спрямовують поведінку, і сукупність мотивів, і пробудження, що активує організм, визначає його напрям. Тобто, як сукупність факторів, що спрямовують, спонукають поведінку людини. А також, мотивація - це процес регуляції конкретної діяльності людини.

Для більш глибокого розуміння проблеми «включення» мотивації в процес навчання, пізнання необхідно позначити відмінності між мотивацією і стимуляцією. Мотивація - це внутрішній процес, заснований на суто особистісних мотивах, тобто імпульсах, що спонукають людину прикладати зусилля і наближають носія мотивів до досягнення певних цілей або задоволення потреб його власними силами, його енергією, за його ж волею. Так, мотивація, маючи внутрішні, частково психологічні причини, не може бути впроваджена ззовні, іншою людиною. Отож, відповідальність за мотивацію належить повністю самій людині (іноді це називається «внутрішня мотивація» або «самомотивація») (Догнал, 2017).

Як зазначає Й. Догнал, викладачі можуть викликати, підтримувати, розвивати ззовні ті імпульси, які індукують мотивацію, тобто лише стимулювати, що в деяких джерелах ще називають «зовнішньою мотивацією». Отже, за ефективність процесу навчання відповідають обидві сторони - і викладачі, і студенти, через з'єднання, взаємодоповнення мотивації й стимуляції дійсно відбувається ефективний процес навчання (Догнал, 2017). Враховуючи мотивацію, стимуляцію і фактори, що впливають на ці процеси, нескладно буде домогтися потрібного результату на практиці. 
При такій організації освітнього процесу студент повинен бути дійовою особою, а викладач - його партнером в навчанні й розвитку. Для підвищення мотивації студента до навчання необхідно проєктувати нові навчальні програми на інноваційних принципах навчання.

Ставлення студентів до свого навчання у закладах вищої освіти залежить від чинників вибору професії, спеціальності і від ставлення до самого процесу навчання. Обираючи професію, студенти проявляють таку позитивну мотивацію: інтерес до професії та бажання в майбутньому займатися саме цією професійною діяльністю, бути корисним людям, суспільству результатами своєї праці, прагнення служити Україні та ін. Трапляються і дещо інші мотиви вибору: соціальний престиж професії, вплив батьків, старших членів сім'ї, позиція друзів, випадковий збіг обставин тощо.

В процесі навчання у ЗВО розвиток пізнавальних $\mathrm{i}$ професійних мотивів $\epsilon$ центральним ланцюгом всього процесу розвитку особистості майбутнього фахівця. Отож, під мотивами професійної діяльності розуміється усвідомлення предметів актуальних потреб особи (здобуття вищої освіти, саморозвитку, самопізнання, професійного розвитку, підвищення соціального статусу i т.ін.), навчальних завдань, що задовольняються за допомогою виконання, спонукаючи іiї до вивчення майбутньої професійної діяльності. Якщо студент розуміє, що за професію він обрав і вважає іiі гідною і значущою для суспільства, це безумовно, впливає на те, як складається його навчання.

Мотивація є основною рушійною силою будь-якої діяльності людини і професійна діяльність не $є$ виключенням. Мотивація є одним із ведучих факторів успішного навчання молодої людини, а отже її професійного становлення. Формування позитивної навчальної мотивації у студентів є умовою ефективної професійної підготовки та розвитку особистості.

Навчально-професійна діяльність - основна діяльність у закладі вищої освіти, завдання якої є підготовка спеціаліста з вищою освітою. Потреба у вищій професійній освіті $\epsilon$ суспільна потреба, яка відповідає сучасному етапу розвитку суспільства: форма освіти реалізована у структурі навчального закладу, зміст реалізований у системі професійних знань, які потрібно засвоїти. Психологічно в окремій особистості форма та зміст освіти виявляються різними потребами: професійною та пізнавальною потребами (інтерес до знань), потребою у вищій освіті (прагнення до певного статусу в суспільстві).

Професійна мотивація складається 3 таких структурних компонентів, як: мотивація ініціації (спрямування до діяльності); мотивація селекції (допомагає у виборі цілі); мотивація реалізації (контроль і регуляція за реалізацію виконання відповідних дій); мотивація пост реалізації (уможливлює завершення дії та спонукає до іншої) (Єрохін, 2011).

Під професійною мотивацією нами розуміється сукупність чинників і процесів, які, знаходячи відбиток у свідомості, спонукають і спрямовують особистість до вивчення майбутньої професійної діяльності. Професійна мотивація виступає, як внутрішній рушійний чинник розвитку професіоналізму особи, оскільки лише на основі іiі високого рівня формування можливий ефективний розвиток професійної й утвореної культури особи.

В навчанні можна виділити декілька етапів, проаналізувавши особливості розвитку навчальної діяльності студентів: етап з високим рівнем показників професійно-навчальної мотивації, мотиви ідеалізуються, тому що обумовлені розумінням суспільного сенсу; на наступному етапі пізнавально-професійні мотиви не керують навчальною діяльністю, спостерігається загальне зниження мотиваційних компонентів; заключний етап відрізняється тим, що підвищується усвідомленість, інтеграція різних форм мотивів навчання. В міру 
засвоєння майбутньої професії змінюються і мотиви поведінки студентів. В період професійної підготовки вони, зазвичай, закріплюються та розвиваються. Від особливостей динаміки мотивацій залежить загалом ставлення до навчальної, а пізніше до професійної діяльності. Лише при сформованому мотиваційному і ціннісному ставленні може відбутися становлення майбутнього спеціаліста як висококваліфікованого фахівця. Професійна освіта зазнає проблем при переході від навчальної діяльності, якою активно займається студент до засвоєння ним професійної діяльності, тобто мотиви студента трансформуються у професійні мотиви фахівця. Отже, мотивація студентів змінюється при навчанні у закладі вищої освіти.

Аналізуючи інформацію щодо професійної мотивації навчальної діяльності, можна визначити умови, які впливають на формування позитивних мотивів навчальної діяльності: високий рівень професіоналізму викладача, вміння і бажання навчати; ставлення до студента 3 повагою як до компетентної особистості; допомога студенту в самопізнанні й самовизначенні, формування позитивних емоцій у студента; планування та організація навчання як процесу пізнання; використання прийомів і методів, що стимулюють навчальну та пізнавальну діяльність; бачення та усвідомлення найближчих і кінцевих цілей навчання; професійне спрямовання навчальної діяльності (Черняк, 2013). Професійна мотивація, як властивість особистості, є системою цілей і потреб, що спонукають студентів до активного засвоєння знань, оволодіння вміннями, свідомого ставлення до професії (Пінська, 2009).

Для підвищення мотивації студентів до навчання педагогіка налічує безліч прийомів і методів. Розглянено деякі з них, а саме: використання IT-технологій; введення системи 3 публікацією успіхів студентів і системи рейтингу їхніх оцінок; формування позитивного, сприятливого психологічного клімату для розвитку особистості; симулювання в процесі навчання ситуації реального життя (рольові ігри); збільшення можливостей самореалізації і введення індивідуальної траєкторії навчання студентів.

3 точки зору Н. Черняк, перед викладачем стоїть завдання створення ситуації успіху, а студент повинен скористатись цією ситуацією. Отже, щоб негативне ставлення до навчання змінити на позитивне, активне і творче, необхідна ситуація успіху. Почуття вдачі, радості, інтелектуального підйому в процесі розв'язання навчальних завдань виникають завдяки позитивним емоціям, а це приносить задоволення. Студенти бажають, з'являється мотив виконувати більш складніші завдання, виникає усвідомлення того, що недостатньо своїх знань, умінь, формується стійка потреба у навчанні (Черняк, 2013).

Сформувати професійні мотиви навчання у студентів, виробити в них потребу в опануванні професійними знаннями, уміннями та навичками - це важливе завдання вищої школи. Мотивація самоствердження допомагає студентам досягати успіху в навчанні, розкриває наполегливість до результатів своєї діяльності, з'являється зацікавленість показувати реальні та можливі досягнення. Мотивація досягнення успіху визначає любов і захоплення своєю роботою, допомагає студентам бути ініціативними та створювати творчу атмосферу для пізнання. Вони показують високі результати у навчальній діяльності.

Для формування позитивної мотивації навчально-професійної діяльності студент повинен стати іiі суб'єктом: 1) виявляти вільну пізнавальну активність, інтелектуальну ініціативу і самостійність у прийнятті рішень щодо вибору шляхів і змісту самоосвіти; 2) збагачувати свій внутрішній світ, бути відкритим новому досвіду; 3) в діях сьогодення орієнтуватися на своє майбутнє, будувати особистісну перспективу; мотивація навчання посилюється, якщо студент бачить зв'язок між засвоєнням знань, збагаченням власного досвіду та вимогами й функціями майбутньої професійної діяльності; 4) розвивати 
рефлексивні процеси: самооцінку, самокритичність; 5) виховувати в собі потребу втілювати в життя власні плани, реалізовувати потенційні можливості. Лише за наявності у студента потреби в самореалізації розвиваються його загальні й професійні здібності, успішно здійснюється теоретична і методична професійна підготовка, формується духовна і моральна вихованість. Процес навчання для нього набуває життєвого смислу, і він працює на вищому рівні активності.

Для того, щоб робота по формуванню адекватної навчально-професійної мотивації студентів мала послідовний i систематичний характер, викладачам необхідно бути обізнаними у специфіці вияву спонукальних причин навчання студентів та динаміці їх ставлень до подальшої роботи. В 2020 році на базі Київського національного університету технологій та дизайну, факультету індустрії моди, кафедри професійної освіти в сфері технологій та дизайну нами було проведено дослідження навчально-професійної мотивації майбутніх педагогів, у якому взяли участь 30 студентів бакалаврського та магістерського рівнів навчання, які навчаються за спеціальністю 015 Професійна освіта (Технологія виробів легкої промисловості).

Для вивчення мотивації навчальної діяльності студентів 4 і 5 курсів освітньої програми «Професійна освіта. Технології виробів легкої промисловості» запропоновано такі методики: «Вивчення мотивів навчальної діяльності студентів» (А. Реан, В. Якунін); «Мотивації навчання у вузі» (Т. Ільїна) та розроблена нами анкета.

Методика «Вивчення мотивів навчальної діяльності студентів» (А. Реан, В. Якунін) передбачає проведення якісного аналізу провідних мотивів навчальної діяльності. Студентам було запропоновано список мотивів, із-поміж яких потрібно було обрати п'ять найбільш значущих. В усій вибірці було визначено частоту вибору того чи іншого мотиву, тобто ієрархію мотивів.

В результаті проведеного дослідження з'ясовано, що провідними для студентів $є$ такі мотиви (табл. 1):

1. Стати висококваліфікованим фахівцем ( $80 \%$ студентів).

2. Набути глибоких і стійких знань (70\% студентів).

3. Отримати інтелектуальне задоволення (70\% студентів).

4. Забезпечити успішність майбутньої професійної діяльності (66,6\% студентів).

5. Отримати диплом (50\% студентів).

Таблиия 1

Результати за методикою «Вивчення мотивів навчальної діяльності студентів»

(А. Реан, В. Якунін)

\begin{tabular}{|l|l|c|c|}
\hline \multirow{2}{*}{$№$} & \multicolumn{1}{|c|}{ Мотиви навчання студентів } & $\%$ & $\begin{array}{c}\text { Кількість } \\
\text { студентів }\end{array}$ \\
\hline 1 & Стати висококваліфікованим фахівцем & $80 \%$ & 24 \\
\hline 2 & Набути глибоких і стійких знань & $70 \%$ & 21 \\
\hline 3 & Отримати інтелектуальне задоволення & $70 \%$ & 21 \\
\hline 4 & Забезпечити успішність майбутньої професійної діяльності & $66,6 \%$ & 20 \\
\hline 5 & Отримати диплом & $50 \%$ & 15 \\
\hline
\end{tabular}

Очевидно, що студенти провідним в процесі навчання в університеті вважають профільний мотив, а саме мотив «стати висококваліфікованим фахівцем», і це дуже важливо, 
оскільки основним завданням при підготовці майбутнього професіонала $є$ формування професійно-значущих властивостей. Отже, можна визнати, що сьогоднішні студенти i завтрашні фахівці найбільше орієнтовані на ставлення себе як майбутнього професіонала.

Навчально-пізнавальний мотив «набути глибокі і міцні знання» також є важливим для опитуваних студентів. Якщо основним завданням студента є отримання знань, які він зможе застосувати в своїй подальшій професійній діяльності, то він буде максимально націлений на освоєння освітньої програми у ЗВО. Варто звернути увагу і на такий мотив пізнавальної діяльності, як «отримати інтелектуальне задоволення». Важливо організувати навчальний процес так, щоб він викликав розумове напруження, бажання розібратися з складними завданнями, що надасть студентам можливість отримувати інтелектуальне задоволення від процесу навчання.

Становлення майбутнього професіонала починається ще в період навчання у 3ВО, коли студент засвоює знання, вміння і навички, професійну етику й професійні категорії, 3 якими він згодом він буде стикатися. Саме це підтверджує четверта позиція професійного мотиву «забезпечити успішність майбутньої професійної діяльності».

Останнім з безперечно значимих мотивів був визначений мотив уникнення «отримати диплом». Це своєрідний матеріальний результат, фізичне підтвердження того, що людина має професійну освіту. На жаль, в умовах сучасності цей мотив часто є основним, і сам факт отримання диплома є для багатьох студентів самоціллю.

Отже, в багатьох студентів провідними мотивами навчання $є$ пізнавальні й професійні. Вибір цих мотивів засвідчує присутність у структурі внутрішньої мотивації пізнавального інтересу, що важливо при виконанні ними навчальної діяльності. Однак зазначимо, що хоча ці мотиви і не є провідними, але у $30 \%$ студентів (9 опитуваних) присутній зовнішній мотив схвалення з боку батьків, оточуючих, а у 6 студентів (20\%) - отримання поваги викладачів.

На дослідження професійної мотивації була спрямована методика «Мотивації навчання у виші», запропонована Т. Ільїною. Ця методика має три шкали:

- «набуття знань» (прагнення до отримання знань, допитливість);

- «оволодіння професією» (прагнення оволодіти професійними знаннями та сформувати професійно важливі властивості);

- «отримання диплома» (прагнення придбати диплом при формальному засвоєнні знань, прагнення до пошуку обхідних шляхів при здачі іспитів і заліків).

Переважання мотивів за першими двома шкалами свідчить про адекватний вибір студентом професії і задоволеністю нею. Методика дозволяє з'ясувати домінування кількісно того чи іншого мотиву.

Таблиия 2

Результати за методикою «Мотивації навчання у виші» (Т. Ільїна)

\begin{tabular}{|l|l|c|c|}
\hline \multicolumn{1}{|c|}{ № } & \multicolumn{1}{|c|}{ Мотиви навчання студентів } & $\%$ & $\begin{array}{c}\text { Кількість } \\
\text { студентів }\end{array}$ \\
\hline 1 & Оволодіння професією & $43,3 \%$ & 13 \\
\hline 2 & Набуття знань & $36,6 \%$ & 11 \\
\hline 3 & Отримання диплома & $20 \%$ & 6 \\
\hline
\end{tabular}

Кількісні результати за цією методикою підтверджують результат, отриманий за допомогою методики «Вивчення мотивів навчальної діяльності студентів», розробленої 
А. Реан і В. Якуніним: домінуючим мотивом у зазначеній групі $є$ мотив оволодіння майбутньою професією. В 43,3\% опитаних студентів цей мотив виявився провідним. Отже, студенти вважають цей мотив основним у своїй навчальній діяльності, тобто прагнуть оволодіти професійними знаннями і сформувати професійно важливі властивості. На другому рівні, із середнім показником $36,6 \%$, був визначений мотив навчання, який виявив інтерес опитуваних до набуття знань і прагнення долати труднощі під час їх отримання. Найнижчий показник має мотив отримання диплома, 20\% опитуваних студентів вважають цей мотив основним. Що може бути пов'язано зі зростаючою престижністю вищої освіти, але і одночасно також з прагненням придбати диплом при формальному засвоєнні знань i мінімальних зусиллях в процесі навчання.

За результатами анкетування визначено, що переважна більшість студентів (93,3\%) задоволені методами навчання та викладання психолого-педагогічних дисциплін і дисциплін технічного циклу (63,3\%). Дані аналізу свідчать про те, що сучасна молодь розуміє важливість вищої освіти сьогодні $(83,3 \%)$. Уявлення студентів про якість освіти, яку вони здобувають, дійсно досить позитивне (70\%). Позитивно впливають на внутрішню мотивацію високий професійний рівень викладачів та їхнє партнерське ставлення до студентів. Аналіз опитування показав, що більшість досліджуваних мають професійні мотиви (30\%), навчально-пізнавальні мотиви (30\%), комунікативні мотиви до навчання (20\%), мотиви творчої самореалізації мають (10\%), соціальні мотиви (10\%). Серед мотивів навчальної діяльності студентів на першому місці «Професійні мотиви» та «Навчально-пізнавальні мотиви», на другому - «Комунікативні мотиви». Загальний стиль життя, який склався на кафедрі професійної освіти в сфері технологій та дизайну, в окремих групах та вплив на них керівництва і самих викладачів є достатньо сприятливим. Студенти підтвердили наявність доброзичливого психологічного клімату в колективі (90\%). Як позитивний момент варто зазначити те, що більшість студентів відчувають допомогу куратора, а в разі виникнення проблеми значна кількість опитаних засвідчила, що буде звертатися до куратора (60\%) та завідувача кафедри (30\%). Для розуміння загальної ситуації з роботою серед студентів варто відзначити, що $60 \%$ респондентів суміщає навчання з роботою, з них - 83,3\% працюють не за спеціальністю. Натомість після закінчення навчання, більшість майбутніх педагогів мають намір шукати роботу за фахом, при цьому, рівень заробітної плати та прагнення мати свою справу є найважливішими критеріями. Як позитивну тенденцію, можна схарактеризувати той факт, що 50\% опитаних спокійно, але, без особливих ілюзій, «дивляться в майбутнє» і 40\% 3 надією й оптимізмом. Також встановлено наявність потенціалу, який можна з успіхом використовувати для творчої співпраці студентів і науково-педагогічних працівників.

Перша та друга методики показали, що для студентів четвертого та п’ятого курсів значущими $є$ не лише професійні та навчально-пізнавальні мотиви, але й мотиви отримання диплому, отримання схвалення з боку інших (зовнішні мотиви щодо навчальної діяльності). Анкетування підтвердило, що значущими для студентів $є$ навчально-професійні мотиви, а також важливість комунікативних мотивів. Такі мотиви навчальної діяльності можуть бути пов'язані зі специфікою професійної діяльності педагога. Отримані результати можливо пояснити особливостями розвитку особистості, на старших курсах у студентів у більшій мірі виявляється готовність працювати за спеціальністю, приносити користь суспільству, у більшій мірі вони орієнтовані на здобуття професійних компетенцій. 


\section{Висновки}

Отже, за результатами дослідження встановлено, що, переважно, студенти четвертого і п’ятого курсів за спеціальністю 015 Професійна освіта (Технологія виробів легкої промисловості) мають достатньо високий рівень навчальної мотивації: спрямованість на здобуття знань, оволодіння професією. Але виявлена група студентів з середнім і низьким рівнем навчальної мотивації, для якої значущі зовнішні мотиви навчальної діяльності: отримання схвалення батьків, викладачів, отримання диплому, комунікативні мотиви (обмін інформацією між людьми для досягнення взаєморозуміння, з метою взаємодії).

Вважаємо, що для підвищення рівня підготовки сучасних фахівців до успішної конкурентоспроможної професійної діяльності на світовому ринку праці суттєвим завданням $\epsilon$ розвиток професійної мотивації студентів у закладах вищої освіти, доцільним є створення системи психологічного супроводу професіоналізації майбутніх фахівців з метою виявлення основних проблем, пов'язаних з початковим етапом професійної кар'єри майбутніх фахівців і для сприяння їх позитивному вирішенню.

Мотивація є одним з провідних чинників успішного навчання. Але особливості цього фактора і його дієвість розрізняються на різних етапах навчального процесу, від першого до останнього курсу змінюєтьс, як навчально-професійна діяльність, так і ії мотивація.

Подальші дослідження будуть спрямовані на вивчення мотивації навчальної діяльності студентів різних курсів спеціальності 015 Професійна освіта (Технологія виробів легкої промисловості) для аналізу динаміки від першого курсу до четвертого. Опанування професійними компетенціями залежить від навчальної мотивації, тому важливо досліджувати психолого-педагогічні умови формування професійних $\mathrm{i}$ навчальнопізнавальних мотивів навчальної діяльності студентів.

\section{Література}

1. Гуртовенко, Н. (2017). Критерії оцінки, показники та рівні психологічної готовності майбутніх педагогів до професійної самореалізації. Психологічний часопис, 3(4), 53-65. https://doi.org/10.31108/1.2017.4.8.5

2. Догнал, Йозеф (2017). Мотивация студентов к обучению и ее барьеры (эссе, основанное на опыте обучения иностранным языкам). Режим доступа: https://www.meteorcity.top/motivacia-studentov-i-ee-baryery

3. Занюк, С.С. (2001). Психология мотивации: Теория и практика мотивирования. Мотивационный тренинг. Киев : Эльга-Н, Ника-Центр.

4. Єрохін, С.А., Нікітін, Ю.В., \& Нікітіна, І.В. (2011). Концепція професійної мотивації студентів як фактор конкурентності на ринку праці. Юридична наука, 1, 20-28.

5. Матвеєва, Н. (2017). Особливості підвищення якості професійної підготовки майбутніх педагогів на сучасному етапі. Освітній простір Украӥни, 9, 96-102. https://doi.org/10.15330/esu.9.96-102.

6. Пінська, О. (2009). Професійна мотивація як засіб підвищення ефективності навчальної діяльності студентів. Проблеми трудової і професійної підготовки, 14, 111-115.

7. Скорик, Т.В. (2020). Моніторингове дослідження розвитку професійної успішності майбутніх учителів. Педагогічний альманах, 46, 208-214. https://doi.org/10.37915/pa.vi46.129

8. Товканець, Г., Авшенюк, Н., Бокша, Н., Брижак, Н., Горват, М., Котун, К., та ін. (2018). Педагогічна освіта і професійна підготовка в сучасному сочіокультурному середовищі. (Монографія). Мукачево : Редакційно-видавничий центр МДУ. 
9. Черняк, Н.О. (2013). Формування мотивації студентів до навчання у ВНЗ. Проблеми інженерно-педагогічної освіти, 38-39, 388-393.

10. Seifert, Tim. (2004). Understanding student motivation. Educational Research, 46, 137-149. https://doi.org/10.1080/0013188042000222421

11. Wijnia, L., \& Servant-Miklos, V.F.C (2019). Lagging behind the Times: A Brief History of Motivational Discourse in Problem Learning. Advances in Health Sciences Education, 24, 915929. https://doi.org/10.1007/s10459-019-09923-3

\section{References}

1. Hurtovenko, N. (2017). Kryterii otsinky, pokaznyky ta rivni psykholohichnoi hotovnosti maibutnikh pedahohiv do profesiinoi samorealizatsii. [Evaluation criteria, indicators and levels of psychological readiness of future teachers for professional self-realization]. Psykholohichnyy chasopys - Psychological Journal, 3(4), 53-65. https://doi.org/10.31108/1.2017.4.8.5 [in Ukrainian].

2. Dognal, Jozef. (2017). Motivacija studentov $k$ obucheniju i ee bar'ery (jesse, osnovannoe na opyte obuchenija inostrannym jazykam). [Motivation of university students (essay based on the experience of teaching foreign languages)]. Retrieved from https://www.meteorcity.top/motivacia-studentov-i-ee-baryery [in Russian].

3. Zanyuk, S.S. (2001). Psihologiya motivatsii: Teoriya i praktika motivirovaniya. Motivatsionnyiy trening. [Psychology of Motivation: Theory and Practice of Motivation. Motivational training.]. Kyiv : Elga-N, Nika-Tsentr [in Russian].

4. Yerokhin, S.A., Nikitin, Yu.V., \& Nikitina, I.V. (2011). Kontseptsiia profesiinoi motyvatsii studentiv yak faktor konkurentnosti na rynku pratsi. [The concept of professional motivation of students as a factor of competitiveness in the labor market]. Yurydychna nauka - Legal science, 1, 20-28 [in Ukrainian].

5. Matveieva, N. (2017). Osoblyvosti pidvyshchennia yakosti profesiinoi pidhotovky maibutnikh pedahohiv na suchasnomu etapi. [Features of improving the quality of professional training of future teachers at the present stage]. Osvitnii prostir Ukrainy - Educational space of Ukraine, 9, 96-102. https://doi.org/10.15330/esu.9.96-102 [in Ukrainian].

6. Pinska, O. (2009). Profesiina motyvatsiia yak zasib pidvyshchennia efektyvnosti navchalnoi diialnosti studentiv. [Professional motivation as a means of improving the efficiency of students' learning activities]. Problemy trudovoi $i$ profesiinoi pidhotovky - Problems of labor and professional training, 14, 111-115 [in Ukrainian].

7. Skoryk, T.V. (2020). Monitorynhove doslidzhennia rozvytku profesiinoi uspishnosti maibutnikh uchyteliv. Pedahohichnyi almanakh - Pedagogical Almanac, 46, 208-214. https://doi.org/10.37915/pa.vi46.129 [in Ukrainian].

8. Tovkanets, H., Avsheniuk, N., Boksha, N., Bryzhak, N., Horvat, M., Kotun, K., et al. (2018). Pedahohichna osvita i profesiina pidhotovka $v$ suchasnomu sotsiokulturnomu seredovyshchi [Pedagogical education and professional training in the modern socio-cultural environment]. Mukachevo : Redaktsiino-vydavnychyi tsentr MDU [in Ukrainian].

9. Cherniak, N.O. (2013). Formuvannia motyvatsii studentiv do navchannia u VNZ. [Formation of students' motivation to study at the university]. Problemy inzhenerno-pedahohichnoi osvity Problems of engineering and pedagogical education, 38-39, 388-393 [in Ukrainian].

10. Seifert, Tim. (2004). Understanding student motivation. Educational Research, 46, 137-149. https://doi.org/10.1080/0013188042000222421.

11. Wijnia, L., \& Servant-Miklos, V.F.C (2019). Lagging behind the Times: A Brief History of Motivational Discourse in Problem Learning. Advances in Health Sciences Education, 24, 915929. https://doi.org/10.1007/s10459-019-09923-3 


\title{
PSYCHOLOGICAL STUDY OF EDUCATIONAL AND PROFESSIONAL MOTIVATION OF FUTURE TEACHERS \\ Rymma Kyrychenko \\ PhD in Psyhology, Associate Professor of the Department of \\ Professional Education in Technologies and Design \\ Kyiv National University of Technologies and Design \\ 2, Nemyrovycha-Danchenka Str., Kyiv, Ukraine, 01011 \\ kirichenkorv11@gmail.com, https://orcid.org/0000-0002-2020-9157
}

\author{
Alla Kolodiazhna \\ PhD in Psyhology, Associate Professor of the Department of \\ Professional Education in Technologies and Design \\ Kyiv National University of Technologies and Design \\ 2, Nemyrovycha-Danchenka Str., Kyiv, Ukraine, 01011 \\ kol-alla@ukr.net, https://orcid.org/0000-0002-5760-883X
}

\begin{abstract}
The main aspects of motivation as a psychological and pedagogical phenomenon are considered in the article. The conditions influencing the formation of positive motives of educational activity and methods of increasing students' motivation to study are analyzed. A questionnaire was conducted and the results of a study of educational and professional motivation of future teachers were described. The goal of the article is to analyze the problem of formation and demonstration of current educational and professional motivation of future teachers to increase the level of training of modern specialists on a specialty 015 Professional Education (Technology of light industry products) in the context of successful competitive professional activity. A set of theoretical and empirical methods was used, which included analysis, synthesis, systematization, comparison and generalization of data on the problem of educational and professional motivation of students, "Methods for diagnosing the learning motivation of students" (A. Rean, V. Yakunin), "Motivation of higher education" (T. Ilyina), questionnaires, surveys and methods of mathematical statistics. According to the results of the study, it is determined that the vast majority of participants are satisfied with the methods of teaching and studying psychological and pedagogical disciplines and disciplines of the technical cycle. The data of the analysis show that modern youth understands the importance of higher education today. In most respondents, the leading motives for learning are cognitive and professional. The analysis of the survey showed that, first of all, the most significant motives of educational activity included the following motives: to become a highly qualified specialist (80\% of students); to acquire deep and stable knowledge (70\% of students); to get intellectual pleasure (70\% of students); to ensure the success of future professional activities (63.3\% of students). The choice of such motives indicates the presence of cognitive interest in the structure of internal motivation, which is very important in the implementation of educational activities. The high professional level of teachers and their partnership with students have a positive effect on internal motivation. After graduation the majority of future teachers intend to look for a job in the specialty, however, the level of salary and the desire to have their own business are the most important criteria. As a positive trend we can highlight the fact that $50 \%$ of respondents look to the future calmly but without much illusion and $40 \%$ - with hope and optimism. The development of professional motivation of students in higher education institutions is an essential task for increasing the level of training of modern specialists for successful competitive professional activity in the world labor market, it is advisable to create a system of psychological support for future professionals to identify key issues related to the initial stage of carreer of future professionals and to promote their positive solution.
\end{abstract}

Keywords: motivation, students, educational motivation, professional motivation, educational and professional activity, formation of positive motivation.

Подано 19.02.2021

Рекомендовано до друку 18.03.2021 